\title{
Online Class Resitation Learning Model During the Covid-19 Pandemic to Increase Outcomes Students Learning in Class Accounting Lessons
}

\section{Xi Department of Accounting Department of State Vocational School 1 Tompaso New Minahasa}

\author{
Meike D. Mamentu, M. $\mathrm{Si}^{1,2}$ \\ ${ }^{1}$ Winangun Palm Bloc.C. Housing. No. 16. Malalayang District, Manado City, Indonesia \\ ${ }^{2}$ Economics Education Study Program, Faculty of Economics, Manado State University, Indonesia \\ Correspondence: Meike D. Mamentu, M. Si, E-mail: meikemamentu@gmail.com
}

Received: September 16, 2021; Accepted: September 29, 2021; Published: January 21, 2022

\begin{abstract}
This study aims to determine the improvement of student learning outcomes through the online class recitation learning model during the covid-19 pandemic, on the learning process of class X1 students of the Accounting Department at SMK Negeri 1 Tompaso Baru Minahasa, totaling 14 students. The online classroom research method used is in the form of CAR (Classroom Action Research) which refers to classroom action research. In terms of treatment, learning is given that applies an online class recitation learning model.

From the results of the analysis obtained by researchers on accounting subjects with service company accounting cycle material with the stages: Recording transactions/documents into general journals (General Entries) and posting from general journals to general ledgers (General Ledger), there is an increase in student learning outcomes. This increase can be seen from the percentage of student learning completeness individually and classically. This increase can be seen from the percentage of student learning completeness individually and classically. At the precycle stage or before the implementation of the action, the average value of the class was 63.92 with the percentage of classical learning completeness only $35 \%$. In the first cycle, it reached an average of 71.78 with a classical mastery level of $64.28 \%$. While the learning outcomes in the second cycle reached an average of 77.85 with the classical learning completeness level reaching $92.85 \%$. Likewise with student learning activities at every face-toface online class. Student activity at the 1 st meeting only reached a percentage of $56.25 \%$ with high criteria. At the second meeting it reached a percentage of $72.76 \%$ with high criteria, and at the third meeting it reached a percentage of $83.92 \%$ with very high criteria. Thus, student learning activities and student learning completeness in online classes during the COVID-19 pandemic increase by using the online class recitation learning model. With learning outcomes reaching $92.85 \%$ above the minimum learning completeness.
\end{abstract}

Keywords: online class recitation learning model, student learning outcomes

\section{Intoduction}

The application of education, where educational actors integrate technology in education as stated by Rusli, M (2009: 25). A teacher is responsible for different lessons by concentrating on developing ICT knowledge skills (information, and communication technology) and transmission knowledge.

Minister of Education and Culture of the Republic Indonesia No. 36962/MPK_A/HK/2020, specifically for areas that have been affected by Covid-19, the following provisions apply:

a) Enforce online learning from home for students and students;

b) Employees, teachers, and lecturers carry out work activities, teach or give lectures from home (Work From Home/BDR) through video conferencing, digital documents, and other online means. For information., various provider institutions have collaborated with the ministry of education and culture, providing free online learning facilities as listed in the appendix which is an integral part of this circular Letter;

c) The implementation of BDR does not affect the level of attendance, considered the same as working in an office, school or college), does not reduce performance, and does not affect performance allowances; and online learning and working from home in order to prevent the spread of the corona virus disease (covid-19). 
WHO has declared the corona virus a pandemic. The term pandemic according to the KBBI is interpreted as an epidemic that spreads simultaneously everywhere, covering a wide geographical area. currently the Covid 19 virus, (covid-19 stands for corona virus disease 2019 which means the Covid-19 corona virus first appeared in 2019) has spread to infect almost all countries in the world.

Considering this, the minister of education and culture of the Republic, of Indonesia issued circular No. 4 of 2020 , regarding the implementation of learning from home to break the Covid-19 chain and carry out online learning.

Due to COVID-19, many schools and colleges were temporarily closed, many students and student staff were carrying out teaching and learning activities from home. The "Learning from home" policy is appropriate to prevent the spread of COVID-19 in the school environment, however the initial and limited survey conducted shows that implementation is still diverse in the field. One form of learning from home is online class recitation learning. This is done so that each student can carry out the learning process as usual but with the form of assignments using different containers and forms, namely by using the internet and e-learning systems. The other facilities such as computers, cellphones, tablets, laptops and learning aids in the form of Zoom, Google Meet, WA, Line etc. Thus, many impacts are generated by the learning process.

Law- the National Education System, Law No. 20 of 2003, Article 3 states that National Education functions to develop and shape the character and civilization of a dignified nation in order to educate the nation's life. Aims to develop the potential of students to become human beings who believe and fear god almighty, have noble character, are healthy, know ledgeable, capable, creative, independent, and become democratic and responsible citizens. RI Law. No.20 of 2003, concerning the National Education System Article 38. Says: "The basic framework and structure of the basic and secondary education curriculum is set by the government". Especially during the Covid19 pandemic. Teachers as education personnel based on PP.No. 17 of 2010, Chapter XII, Article 171 Paragraph 1 concerning "Education Managers and Organizers" Chapter XII Article 171, says: "Educators are qualified education personnel as teachers, lecturers, counselors, tutors, widyaiswara, tutors, instructors, facilitators and other designations that are appropriate to their specificity and participate in providing education. Especially implementing education during the COVID-19 pandemic.

To achieve these educational goals, the government has sought to improve the quality of education starting from the basic education level to the university level. One of them is by improving the curriculum and its application in the activities of the learning process. In addition, the government also undertakes efforts such as upgrading of teachers in the field of study, procurement of textbooks, and also adding facilities and infrastructure to meet the needs of teaching and learning activities.

However, the most influential component in the process to develop the potential of students is the educators themselves, namely teachers. This is very reasonable because the teacher is the spearhead who deals directly with students as subjects and objects of learning. However good and ideally the educational curriculum is formed, however complete the educational facilities and infrastructure are without being balanced with the teacher's ability to implement them, all of that will be less meaningful ( Note 1). In other words, the teacher occupies a central point or a very important factor in education. The teacher's very important role is to activate and streamline the learning process in schools, including the use of appropriate teaching methods. In delivering the material, a teacher must choose which method is appropriate to the state of the student's learning class, so that students feel interested in following the lessons being taught. Teachers who can use a variety of learning process methods can improve student learning activities (Note 2).

In fact, the level of completeness of student learning outcomes before the covid 19 pandemic in accounting subjects at SMK Negeri 1 Tompaso Baru class XI majoring in accounting is still relatively low at $65 \%$ of the total 14 students. The minimum completeness criteria (KKM) set by the school and implemented by the subject teacher is 70 for the achievement of learning mastery. After the pandemic, classically, this percentage has not reached the learning completeness standard set by the school, which is $>80 \%$, thus the learning process and learning outcomes have not been said to be complete.

Based on the results of initial observations in the field and interviews with teachers in the field of accounting at SMK Negeri 1 Tompaso Baru in collaboration with multimedia teachers before the COVID-19 pandemic, the learning method used by teachers in the teaching and learning process is generally the lecture or classical method. The lecture method is very economical and efficient if it is used for the purpose of delivering information and understanding. But there are also weaknesses, namely students tend to be passive and have not fully involved students in actively learning in the learning process, and some students become lazy to ask questions. Students are also only glued to the teacher's explanation and take notes on the material presented by the teacher without understanding what he wrote. When given exercises or tests students find it difficult to complete their work. Some of them only copy the work of their friends. Students cannot try to work on the questions given themselves. When they are asked to present or account for their work in front of the online class, they cannot do it optimally. Because 
it is not the result of their own thoughts. In the end, it will affect student learning outcomes that have been determined by the subject teacher and do not reach the minimum learning completeness criteria (KKM) of 70 .

On the problems above, efforts should be made to improve learning processes and methods in order to achieve the learning objectives that have been set. Learning currently uses online and offline learning processes during the Covid 19 pandemic. Learning from the teacher's home must use the right method in the classroom. Teachers carry out assignments from home online and offline. and students study from home online and offline. For this reason, teachers are required to not only convey material orally in using online classes or lectures through social media tools in online classes but must choose methods that can train students to learn actively, independently and responsibly.

One method that can be used to involve students in active, independent and responsible learning in the learning process is to use the recitation method in online classes. In other words, the recitation method is an assignment method, where students are given the freedom to understand a concept by seeking or digging information from the tasks given. These tasks can be done or done at home, and using internet media online, and can explore material from various learning sources related to the material being studied. The recitation method can also stimulate students' desire to further deepen their knowledge of something they just know. In addition, the recitation method will also make students more responsible for what they have done because students are asked to present or explain the results of their thoughts through online classes. The more students' activities in learning, the students' understanding will also increase. Based on the background of the problems above and the advantages of the online class recitation learning method, it can be seen in the results of classroom action research to improve student learning outcomes. Because learning outcomes are changes in behavior, and real learning outcomes from the behavior of students (Note 3).

\section{Research Methods}

\subsection{Online Classroom Research Method}

The method used in this research is an online classroom action research (CAR). In collaborative research, the party who takes the action is the teacher of the online classroom study itself and the multimedia teacher, while the researcher who observes the ongoing action process is the researcher (Note 4). According to Kemmis and Taggart; There are several stages in this research (Note 5), namely:

a) Planning (Plan); b) Action (Act); c) Observation (Observe); d) Reflection

For this learning stage, it is necessary to design learning activities. Hamzah B.Uno (2011: 112) Says: The design of learning activities (RKP) is a set of writings containing lesson plans and practicums from lecturers or teaching staff in giving lectures or practicums. The learning activity plan must formulate clear and implementable learning objectives. Furthermore, (Note 6) Syafruddin Nurdin, Adriantoni (2006: 95), said: The learning implementation plan (RPP) is a short-term plan to estimate or project what will be done in learning. There are two functions of RPP, namely: Planning function and implementation function.

\subsection{Learning Media}

The learning tools used in this research are:

a) RPS (Semester Learning Implementation Plan) in online classes.

That is a guideline compiled systematically by researchers in collaboration with subject teachers and multimedia teachers which contains the steps for delivering learning materials by applying the recitation method.

b) Student Worksheet (LKS)

Namely in the form of homework that must be done by students during the learning process in online classes and distance learning.

\subsection{Data Collection Technique}

In online classroom action research, data collection is carried out using the following techniques: Observation and Test. The type of instrument used is in the form of student activity observation sheets and written test instruments.

a) Observation or observation techniques used to collect data about student activities during the teaching and learning process (KBM) in online classes/distance learning and apply the recitation method in online classes.

b) The test technique used to collect data about student learning outcomes in accounting subjects regarding service company accounting cycle materials, the stages are recording and documenting transactions into general journals (General Entries). Posting from the general journal to the general ledger is carried out in online classes and collaboration with distance learning, homework assignments. 


\subsection{Data Analysis Technique}

The data analysis technique used in this research is qualitative data analysis which by Lexy J. Moleong, (2000: 15) says qualitative research is research called naturalistic inquiry or natural inquiry, and uses quantitative data. Furthermore (Note 7), Suharsimin Arikunto (2010: 268) said: Research that uses a lot of descriptive qualitative analysis is evaluation research. (Note 8) This study aims to assess the extent to which the variables studied are in accordance with predetermined benchmarks. The benchmarks for the descriptor in question are, for example, benchmarks for the formulation of student-centered learning objectives, measuring only one aspect, success can be observed, and there are demonstration conditions that can be displayed. The four benchmarks are rated 5 as the maximum value where the variables studied meet the specified size. The descriptive analysis said that the condition of the variable had $100 \%$ met the desired or expected conditions.

\section{Qualitative Data Analysis}

To find out how active students are in participating in the learning process in online class accounting subjects and distance learning with the recitation method (home work), the analysis is carried out on the observation sheet instrument using formulas through percentages. (Note 9)

The formula used is:

$$
P k=\frac{S}{S N \times S M} \times 100 \%
$$

Explanation:

$$
\begin{aligned}
\mathrm{Pk}= & \text { Percentage of Student Activity } \\
\mathrm{S}= & \text { Total Score } \\
\mathrm{SN}= & \text { Number of Students } \\
\mathrm{SM}= & \text { Maximum Score } \\
& \text { (Acep Yonny, et al 2010: 175-176) }
\end{aligned}
$$

The criteria for the percentage of student learning activities in the learning process according to Acep Yonny et al (2010: 175-176) as shown in table 3.1 below:

Table 3.1 Criteria for the Percentage of Student Learning Activities:

\begin{tabular}{ll}
\hline PERCENTAGE & CRITERIA \\
\hline $75 \%-100 \%$ & Very high \\
$50 \%-74,99 \%$ & High \\
$25 \%-49,99 \%$ & Moderate \\
$0 \%-24,99 \%$ & Low \\
\hline
\end{tabular}

\subsection{Data Analysis}

The formulas used to process data on student learning outcomes are:

a) To determine the final value of learning outcomes obtained by each student (BSNP 2007: 25):

$$
\mathbf{N A}=\frac{\mathrm{SP}}{\mathrm{SM}} \times 100 \%
$$

Information: $\mathrm{NA}=$ Final Score; $\mathrm{SP}=$ Gain Score; $\mathrm{SM}=$ Maximum Score

b) To determine the average grade point (Nana Sudjana, 2010: 125): (Note 10)

$$
\mathbf{N R}=\frac{\mathbf{N A}}{\mathbf{S N}}
$$

Information: $\mathrm{NR}=$ Average Score; $\mathrm{NA}=$ Final Score; $\mathrm{SN}=$ Number of Students

c) To determine the level of classical learning completeness according to Zainal Aqib et al., (2010: 41): (Note 11)

$$
\text { TBK }=\frac{\mathbf{N}}{\mathbf{S N}} \times 100 \%
$$

Information: TBK = Completed Classical Learning; $\mathrm{N}=$ Number of students who get a score $>70$

$$
\mathrm{SN}=\text { Number of Students }
$$




\section{Results and Discussion}

\subsection{Pre Cycle}

Classroom Action Research (CAR), online classes with the application of the recitation method can improve student learning outcomes in accounting subjects for Class XI Accounting Department at SMK Negeri 1 Tompaso Baru. The implementation of classroom action research before the online class and after using the resisitas method at SMK Negeri 1 Tompaso Baru in class XI even semester of the 2019/2020. Academic year with the subject of service company accounting sycle stages: (1) Recording transactions/documents into general journals (General Journal Entries), (2) Posting from the general journal to the general ledger. The number of students in this class is 14 people consisting of 7 boys and 7 girls who have online class learning facilities.

Activities carried out during the pre-cycle tend to be activities of forming collaborative networks between researchers and partner teachers, namely subject teachers and multimedia teachers. It should be noted that prior to the implementation of this pre-cycle, the researcher first consulted with the accounting subject teacher and the multimedia teacher. Conduct initial observations to identify problems by observing learning activities in class. In conducting observations, the researcher took a list of daily test scores for students of class XI Accounting Department in accounting subjects with the subject of general journals (General Entries) as initial data in the study before entering Cycle I. For more details, see table 4.1 below:

Table 4.1 Class XI Student Learning Outcomes (Pre-Cycle) Recording Transactions / Documents Into the General Journal

\begin{tabular}{llllll}
\hline No & Student Name & M/F & MCC & Value & Description \\
\hline 1 & Vestia Kamaasi & F & 70 & 65 & Not complete \\
2 & Vicky Nayoan & M & 70 & 60 & Not complete \\
3 & Rilly Ngion & F & 70 & 55 & Not complee \\
4 & Aurilia Wowor & F & 70 & 70 & Complete \\
5 & Lanny Rorong & F & 70 & 70 & Complete \\
6 & Leidia Sumore & F & 70 & 70 & Complete \\
7 & Sweetty Lalogirot & F & 70 & 80 & Complete \\
8 & Thessa Lontoh & M & 70 & 65 & Not complete \\
9 & Karan Singkoh & M & 70 & 60 & Not complete \\
10 & Swindy Walintukan & M & 70 & 50 & Not complete \\
11 & Novita Maspeke & F & 70 & 80 & Complete \\
12 & Visensia Songgigilan & M & 70 & 60 & Not complete \\
13 & Filicia Ardiansyah & F & 70 & 65 & Not complete \\
14 & Febiola Turangan & M & 70 & 45 & Not complete \\
\hline \multicolumn{7}{l}{ Total Value } & & $\mathbf{8 9 5}$ & \\
& Average Score & & $\mathbf{6 3 , 9 2}$ & \\
& Percentage of Learning Completeness & $\mathbf{3 5 \%}$ &
\end{tabular}

In table 4.1, it can be seen that the number of students who complete is less than students who have not completed. Of the 14 students, only 5 students managed to achieve the minimum learning completeness qualification (KKM), 9 students have not reached the KKM so that the percentage of learning completeness obtained is $35 \%$. The average score obtained by class XI students in vocational competence subjects with the subject of the general journal is 63.92, so it still has not reached the KKM determined by the school and carried out by the teacher in the field of expertise. By looking at the results of the data above, it is necessary to take corrective actions in learning through learning by applying the online class recitation method and remote assignments or homework so as to improve student learning outcomes.

\subsection{Cycle I}

\subsubsection{Planning Stage}

Cycle I online class action planning was carried out on tuesday, at the teacher's house and the student's house of SMK Negeri 1 Tompaso Baru. The teacher and the researcher discuss the action plan that will be carried out in this study. The implementation of Cycle I actions will be carried out in 2 meetings, namely on Wednesday, March 11, 2020 and Friday, March 13, 2020.

The action planning stage of the first cycle includes the following activities:

a) Researchers together with subject teachers and multi-media teachers discuss scenarios for online classroom learning in accounting subjects using the recitation method with distance learning assignments. 
b) Researchers develop an online class learning implementation plan (RPS) by distance learning. For the first meeting, the material: recording transactions/documents into the general journal (Appendix 1) and for the second meeting. Material: posting from the General Journal to the ledger (Appendix 2).

c) Researchers compiled essay questions for online classes with homework (assignments) at the first meeting. Material: recording transactions/documents into the general journal (Appendix 4) and for the second meeting, material: posting from the General Journal to the ledger (Appendix 5).

d) The researcher arranged the research instrument in the form of student activity observation sheets for the first meeting (Appendix 7) and for the second meeting (Appendix 8). Observation sheets are used to observe student activities during the online teaching and learning process by distance learning.

e) Researchers develop research instruments in the form of test questions for Cycle I. The test questions cover the following topics: (1) Recording transactions/documents into the general journal and (2) Posting from the general journal to the ledger (Appendix 10). The test instrument is assessed from the results of student work (end-of-cycle evaluation) via WA, email (one line), Zoom, and Google Class Rome.

\subsubsection{Action Implementation Stage}

\section{a) First Meeting}

The first meeting was held on Wednesday, March 11, 2020. The learning process refers to the lesson plan-1 (Appendix 1) with the allotted time of $3 \times 45$ minutes. The main material to be discussed is the accounting cycle of service companies at the stage of recording transactions/documents into the general journal. The method used is the online class recitation learning method by conducting online discussions, then collaborating with distance learning assignments. At the core activity stage (elaboration) the teacher forms study groups in online classes and assigns tasks to each group in the form of practice questions regarding general journals. Next, the teacher explains the accounting cycle of the service company at the stage of recording transactions/documents into a general journal through one-line online class media and using multimedia tools in the form of zoom or google meet and other social media. Students discuss and answer practice questions in groups in online class presentations and then individually in assignments.

At the end of the meeting the teacher gave individual assignments to students to do at home and reported in the form of worksheets (Appendix 4).

\section{b) Second Meeting}

The second meeting was held on Friday, March 13, 2020. The learning process in the online class refers to the Learning Implementation Plan-2 (Appendix 2) with the allocated time of $3 \times 45$ minutes. The subject matter that will be discussed is the second stage of the service company accounting cycle, namely posting from the general journal to the general ledger. The method used is the lecture method and online discussion in collaboration with the recitation learning method (Assignment) with distance learning.

At the end of the meeting the teacher gave individual assignments to students to do at home (Appendix 5). Then the teacher informs the students that for the next meeting there will be a daily test-1 (Postest cycle I) which includes material for recording transactions/documents into the general journal and posting from the general journal to the general ledger. The test was held on Monday, March 16, 2020 in an online class.

\section{c) 1st Daily Test (Posts Cycle I)}

The 1st daily test or posttest will be held on Monday, March 16, 2020. According to the information presented at the second meeting, the materials to be tested include general journals (General Entry) and general ledgers. The data collection instruments used were essay test questions (Appendix 10) and Student Worksheets (LKS) (Appendix 17) which were done individually at home and directly reported the results of work online in online classes using social media such as Zoom, Google Class Rome, WA and email according to the time/hour provided. The first daily test is carried out within $2 \times 45$ minutes, according to the time allocation that has been agreed upon by the teacher and

\subsubsection{Observation Stage}

Observations were carried out simultaneously with learning activities in online classes, in this study the observation phase was carried out to obtain data on how teaching and learning activities were as well as the seriousness and activeness of students in online classes using the recitation learning method. Researchers as observers have observed a series of learning processes that have been carried out by the teacher. The data instrument used was in the form of student activity observation sheets during the teaching and learning process.

From the results of observations during the learning process in cycle II, the following results were obtained: From the teacher's point of view 
a) At the third meeting, the teacher can apply and condition the online class learning recitation method. The teacher explains teaching materials online using learning aids such as google meet, zoom, line, WA, google class rume and others that have been conditioned with students and with the available time according to signal conditions. The online learning process is going well and in accordance with the lesson plans that have been prepared.

b) Teachers are very effective in managing online classes using the recitation method. The time efficiency that has been conditioned by online classroom learning is very adequate in its implementation. Students can complete all assignments given by the teacher. Students can transact and communicate well in teacher-directed online classes. All problems in the discussion of assigned teaching materials can be done well by students with the help and direction of the teacher. The teacher carries out an evaluation at the end of the meeting in the online class. Learning outcomes and learning objectives can be achieved. Teachers can take advantage of online classroom facilities by directing the learning process to student study groups so that individual assignments can be completed by students. At the end of the learning process the teacher evaluates learning outcomes, and learning objectives can be achieved or student learning outcomes increase

c) Teachers have difficulty creating a conducive learning atmosphere when learning takes place online because students sometimes have to find places that can be reached by signals when online classes, but they can do assignments at home after explaining the material through online classes but by conditioning the right time and place.

At the second meeting (Friday, March 13, 2020):

a) The learning activities carried out by the teacher have been carried out well, the online class atmosphere has begun to be controlled because the teacher supervises each group member very carefully following the conditions of the online class by paying attention to the conditions of online class learning. At the same time, all students are ready to learn through online classes. Learning tools use their available social media such as Google Class Rome, Zoom by conditioning signals that all can be reached. Learning is conditioned to be able to take place well and reach all students or students online by using the online class recitation method for assignments.

b) Although the teacher has not fully reached all students to be monitored directly simultaneously, but the results of his work by arranging study times according to signal conditions and homework are limited in time, have been conditioned and determined to be done by students.

c) There is still a lack of direct motivation and guidance but it does not prevent teachers from doing online motivation and guidance to students and in giving assignments (recitations) so that students' difficulties in learning and doing assignments can be overcome to work on each practice question or task given teacher.

\subsubsection{In Terms of Students}

At the First meeting (Wednesday, 11 March 2020):

a) There are still some students who do not want to be actively involved in discussions, they still rely on friends in their groups even though they have entered the online class group in the online class study group.

b) At the task accountability stage, some students still cannot do it optimally, this is because they still lack confidence in expressing their opinions, especially through online classes.

c) Students will only ask the teacher if the teacher takes an online approach in giving homework. Therefore, the role of the teacher as a facilitator is needed in this context.

d) Communication skills in online classes when presentations made by teachers and students are still less effective. The teacher should provide input on how to communicate well at the time of delivering the material and the appropriate steps in giving clear and understandable assignments for students to do. The presentation of online learning outcomes by students has not been maximal in presenting their group assignments. Teachers must provide opportunities for students to provide opinions and questions when delivering online learning materials or assignments.

At the second meeting (Friday, March 13, 2020):

a) Some students still lack concentration in participating in learning when giving apperception, some of them leave the online class because they do not understand what the teacher explains and look for signals that are sometimes lost in online classes.

b) Students have not been able to work well together in their online groups due to limited space and time and available networks.

c) At the time of checking the assignments or responsibilities of the assigned tasks, there were several students, either group assignments or independent assignments, they could not be held accountable because students did not fully understand the material given and their duties so that it affected their learning outcomes. 


\subsubsection{Student Activities}

To determine the success or failure of the application of the online class recitation method on student learning activities in online classes, it can be seen from the results of observations made in online classes during the learning process. Based on observations, it is known that the level of student activity at the 1st meeting reached $56.25 \%$ with High criteria (Appendix 7) and at the 2nd meeting an increase reached $72.76 \%$ with High criteria (Appendix $8)$.

\subsubsection{Reflection Stage}

The value of the evaluation test for learning outcomes in Cycle I can be explained in table 4.2 below:

Table 4.2 Student Learning Outcomes Posttest Cycle Ies

\begin{tabular}{|c|c|c|c|c|c|}
\hline No & Student Name & $\mathrm{M} / / \mathrm{F}$ & MCC & Value & Description \\
\hline 1 & Vestia Kamasih & $\mathrm{F}$ & 70 & 70 & Complete \\
\hline 2 & Vicky Nayoan & $\mathrm{M}$ & 70 & 65 & Not complete \\
\hline 3 & Rilly Ngion & $\mathrm{M}$ & 70 & 60 & Not complete \\
\hline 4 & Aurilia Wowor & $\mathrm{F}$ & 70 & 75 & Complee \\
\hline 5 & Lanny Rorong & $\mathrm{F}$ & 70 & 80 & Complete \\
\hline 6 & Leidia Sumore & $\mathrm{F}$ & 70 & 75 & Complete \\
\hline 7 & Sweetty Lalogirot & $\mathrm{F}$ & 70 & 90 & Complete \\
\hline 8 & Thessa Lontoh & $\mathrm{M}$ & 70 & 70 & Complete \\
\hline 9 & Karan Singkoh & $\mathrm{M}$ & 70 & 65 & Unfinished \\
\hline 10 & Swindy Walintukan & $\mathrm{M}$ & 70 & 65 & Not complete \\
\hline 11 & Novita Maspeke & $\mathrm{F}$ & 70 & 85 & Complete \\
\hline 12 & Visensia Songgigilan & M & 70 & 70 & Complete \\
\hline 13 & Filicia Ardiansyah & $\mathrm{F}$ & 70 & 75 & Complee \\
\hline \multirow[t]{4}{*}{14} & Febiola Turangan & $\mathrm{M}$ & 70 & 60 & Unfinished \\
\hline & \multicolumn{3}{|l|}{ Total Value } & \multicolumn{2}{|l|}{1.005} \\
\hline & \multicolumn{3}{|c|}{ Average Value } & \multicolumn{2}{|l|}{71,78} \\
\hline & \multicolumn{3}{|c|}{ Percentage of Learning Completeness } & $64,28 \%$ & \\
\hline
\end{tabular}

In table 4.2, the implementation of Cycle I in class XI after the recitation method in the online class was applied in the learning process showed that there was an increase in student learning outcomes. This can be seen from the increase in the learning outcomes of class XI students who previously in the pre-cycle (before the application of the recitation method) obtained an average value of 63.92 with classical learning completeness of $35 \%$ of 5 students who achieved the Minimum Completeness Criteria (KKM). > 70, while in the first cycle (after the application of the recitation method) the student learning outcomes obtained an average of 71.78 with classical learning mastery of $64.28 \%$, of the number of students who completed as many as 9 students who were able to achieve the KKM > 70 and who did not complete as many as 5 students who did not reach KKM > 70. It can be concluded that student learning outcomes in the first cycle have not reached the classically planned mastery level of learning that is at least $80 \%$

Based on data analysis and the results of observations of the implementation of online class actions in cycle I, the reflections of these actions are as follows:

a) Teachers should make more efforts to find appropriate strategies, attract students' attention to learning materials delivered online and adjusted to the time and signals available so that students have the motivation to learn.

b) Teachers must be able to manage remote classes that are conditioned well online so that the teaching and learning process can run well.

c) The tasks given should be more varied by paying attention to student learning conditions with available and conditioned social media learning tools. Thus it can avoid boredom and laziness in students to do assignments.

d) Teachers still have to spend extra time to condition online learning time and students' readiness to learn in online classes with conditioned time. Teachers can also carry out activities outside the online or offline classroom to motivate student learning which is followed by strengthening learning materials for students. Remote group and independent study assignments for students can approach and monitor online and offline equally to all students by utilizing all their available social media such as Zoom, Google Class Rome, Google Meet,WA, email and others so that students can actively attend and active in the online class learning process. if every student who experiences learning experiences difficulties in learning online, the teacher must use the recitation learning method through 
online classes and explain appropriately in doing the tasks given and students' learning difficulties become easy and resolved.

e) Teachers must be more creative to create a conducive online learning atmosphere so that students have high learning motivation by using the online class recitation learning method.

f) As much as possible the application of the online class recitation method is carried out optimally and conditioned so that it can involve students learning actively in groups and learning independently and responsibly.

From the problems found in the implementation of the first cycle of actions, the teachers and researchers again made plans for the implementation of online class actions for the next cycle, namely Cycle II by using the online class recitation teaching method.

\subsection{Cycle II}

\section{a) Planning Stage}

Cycle II action planning was carried out on Tuesday, March 17, 2020 in order to carry out online class recitation learning activities. Teachers as teachers and students or students in receiving their lessons at home. The implementation of online class recitation learning at SMK Negeri 1 Tompaso Baru, subject teachers and multimedia teachers together with researchers discussed the design of class actions online. to be carried out in this research. The researcher revealed that based on the results of the analysis and reflection from the first cycle there were still some shortcomings, then it was agreed that the implementation of the second cycle of actions would be carried out in 1 meeting (third meeting), namely on Wednesday 18 March 2020 with the following design:

(a) The researcher and the teacher discussed the scenario of online class learning in accounting subjects using the recitation or assignment method.

(b) The researcher developed a lesson plan (RPS) for the third meeting with the subject of posting from the general journal to the ledger (Appendix 3) using the online class recitation learning method.

(c) The researcher prepares essay questions for homework assignments (assignments) for the third meeting, with the subject of posting from the general journal to the general ledger (Appendix 6) in an online class using the recitation or assignment method.

(d) The researcher arranged the research instrument in the form of student activity observation sheets (LKS) for the third meeting (Appendix 9). Observation sheets are used to observe student activities during the online teaching and learning process using the recitation or assignment method.

(e) Researchers develop research instruments in the form of test questions for cycle II. The test questions cover the subject of: posting from the general journal to the general ledger (Appendix 11). The test instrument is assessed from the results of student work (end of cycle evaluation).

\section{b) Class Action Implementation Stage Darimg}

\section{(a) Third Meeting}

The third meeting was held on Wednesday, March 18, 2020. The time allocation for the third meeting was $3 \times 45$. Learning activities in the online class with the recitation learning method refer to the Lesson Plan-3 (Appendix 3). The subject matter discussed is posting from the general journal to the general ledger. At the end of the third meeting the teacher gave individual assignments to students to do at home (Appendix (b). Then the teacher informs the students that for the next meeting there will be a 2nd daily test (Postest cycle II) which includes general journal (General Entries) and general ledger materials in online classes. The final test of this cycle will be held on Friday, March 20, 2020.

\section{(b) 2nd Daily Test (Postest Cycle II)}

The 2nd daily test or posttest will be held on Friday, March 20, 2020. According to the information presented at the third meeting, the materials to be tested include general journals (General Entry) and general ledgers. The data collection instruments used were essay test questions (Appendix 11) and Student Worksheets (LKS) (Appendix 18). The second daily test is carried out in $2 \times 45$ minutes, according to the time allocation that has been agreed upon by the teacher and researchers in the online class.

\section{- Observation Stage}

Observations were carried out simultaneously with learning activities in online classes, in this study the observation phase was carried out to obtain data on how teaching and learning activities were as well as the seriousness and activeness of students in online classes using the recitation learning method. Researchers as observers have observed a series of learning processes that have been carried out by the teacher. The data instrument used was in the form of student activity observation sheets during the teaching and learning process.

From the observations during the learning process in the second cycle, the following results were obtained: 
- From the teacher's point of view

(a) At the third meeting, the teacher can apply and condition the online class learning recitation method. The teacher explains teaching materials online using learning aids such as google meet, zoom, line, WA, google class rume and others that have been conditioned with students and with the available time according to signal conditions. The online learning process is going well and in accordance with the lesson plans that have been prepared.

(b) Teachers are very effective in managing online classes using the recitation method. The time efficiency that has been conditioned by online classroom learning is very adequate in its implementation. Students can complete all assignments given by the teacher. Students can transact and communicate well in teacher-directed online classes. All problems in the discussion of assigned teaching materials can be done well by students with the help and direction of the teacher. The teacher carries out an evaluation at the end of the meeting in the online class. Learning outcomes and learning objectives can be achieved. Teachers can take advantage of online classroom facilities by directing the learning process to student study groups so that individual assignments can be completed by students. At the end of the learning process the teacher evaluates learning outcomes, and learning objectives can be achieved or student learning outcomes increase.

- In terms of students

(a) At the third meeting, all students were actively involved in extracting information from the given task and were more confident because the level of understanding of the task was already high or understandable. And in taking responsibility for the assignments given, students convey the results of their discussions in online classes. And the material they have acquired in the online class is well understood.

(b) During group discussions, all students are active and have been involved in online class discussions and can carry out the question and answer process well. In online class group discussions in order to answer the tasks given by the teacher, students have no difficulty in completing and answering the questions given to them.

(c) The activeness of students in participating in teaching and learning activities has increased. Students no longer do unnecessary things or leave the online class during discussion because they are well conditioned in terms of time and means of learning online classes with the recitation learning method. And all students understand the teaching material being taught. Students are much more enthusiastic during group discussions during presentations and students do not experience difficulties both in the learning process and in completing the assigned tasks.

(d) Students can work together in groups according to what is assigned to them and they can account for the results of their group discussions in online classes. The group can answer all the questions posed by other study groups in the online class.

(e) Students are able to find their own information about the subject matter from the assignments given even though there are still two or three students who still do not understand what they have learned but they provide explanations to each other, this is because the level of understanding of students is low. different but can be put together through online class discussions under the guidance of the teacher.

c) Student Activities

Based on the observations made, it is known that the student activity at the third meeting in the online class with the recitation learning method reached $83.92 \%$ with very high criteria (Appendix 9).

- Reflection Stage

The value of the learning outcomes evaluation test in Cycle II can be explained in table 4.3 below.

Table 4.3 Student Learning Outcomes of Posttest Cycle II

\begin{tabular}{llllll}
\hline No & Student Name & M/F & MCC & Velue & Description \\
\hline 1 & Vestia Kamasih & F & 70 & 75 & Complete \\
2 & Vicky Nayoan & M & 70 & 75 & Complete \\
3 & Rilly Ngion & M & 70 & 70 & Complete \\
4 & Aurilia Wowor & F & 70 & 80 & Complete \\
5 & Lanny Rorong & F & 70 & 85 & Complete \\
6 & Leidia Sumore & F & 70 & 80 & Complete \\
7 & Sweetty Lalogirot & F & 70 & 100 & Complete \\
8 & Thessa Lontoh & M & 70 & 75 & Complete \\
9 & Karan Singkoh & M & 70 & 70 & Complete \\
10 & Swindy Walintukan & M & 70 & 75 & Complete \\
11 & Novita Maspeke & F & 70 & 95 & Complete \\
12 & Visensia Songgigilan & M & 70 & 70 & Complete \\
\hline
\end{tabular}




\begin{tabular}{llllll}
\hline 13 & Filicia Ardiansyah & $\mathrm{F}$ & 70 & 75 & Complete \\
14 & Febiola Turangan & $\mathrm{M}$ & 70 & 65 & Unfinished \\
\hline \multicolumn{3}{l}{ Total Value } & & $\mathbf{1 . 0 9 0}$ & \\
Average Value & & $\mathbf{7 7 , 8 5}$ & \\
& Percentage of Learning Completeness & & $\mathbf{9 2 , 8 5 \%}$ & \\
\cline { 2 - 3 }
\end{tabular}

In table 4.3, student learning outcomes are obtained in the implementation of the second cycle which includes material on General Journals (General Entries) and General Ledgers. In the implementation of the second cycle, student learning outcomes have increased, with an average value of 77.85 from the number of students as many as 14 students, and those who are able to achieve the Minimum Completeness Criteria (KKM) $>70$ are 13 students and those who do not reach the KKM or are incomplete is 1 student because of his limitations. Thus the level of classical learning completeness is $92.85 \%$. It can be concluded that student learning outcomes in cycle II have reached the classically planned mastery level of learning, which is at least $80 \%$.

Based on the data analysis and the results of the observation of the implementation of the action in cycle II, the reflection of the action is as follows:

a) Teachers are more creative in creating a conducive online classroom learning atmosphere so that students have high interest and motivation to learn.

b) Teachers are more innovative in using various learning methods, especially using the recitation method in the implementation of the online classroom learning process when teaching, so that students are more enthusiastic in participating in lessons and do not get bored quickly.

c) The teacher is able to create a conducive learning atmosphere, so that the learning process runs well in the implementation of online classes.

From the reflection results, it can be seen that the application of the Recitation (Assignment) method in the online class cycle II was considered successful and was considered to be very satisfactory so that it did not need to be continued to the next cycle.

Implementation of Online Classes Using the Recitation Method During the Pandemic Covid 19

d) Student activities in learning with the recitation method in online classes.

Based on the analysis of student activity observation sheets, information was obtained that student activities in online classroom learning activities with the application of the recitation method were classified as good. This means that the actions imposed on students are already running in accordance with the predetermined learning plans. Teachers are able to carry out their role as facilitators so that students are able to be actively involved, independent and responsible in the learning process. Student activity at the 1st meeting only reached a percentage of $56.25 \%$ with high criteria, at the 2nd meeting it reached a percentage of $72.76 \%$ with high criteria, and at the 3rd meeting it reached a percentage of 83.92 with very high criteria. high. The increase in student activity at each meeting can be illustrated by the following bar graph 4.1 :

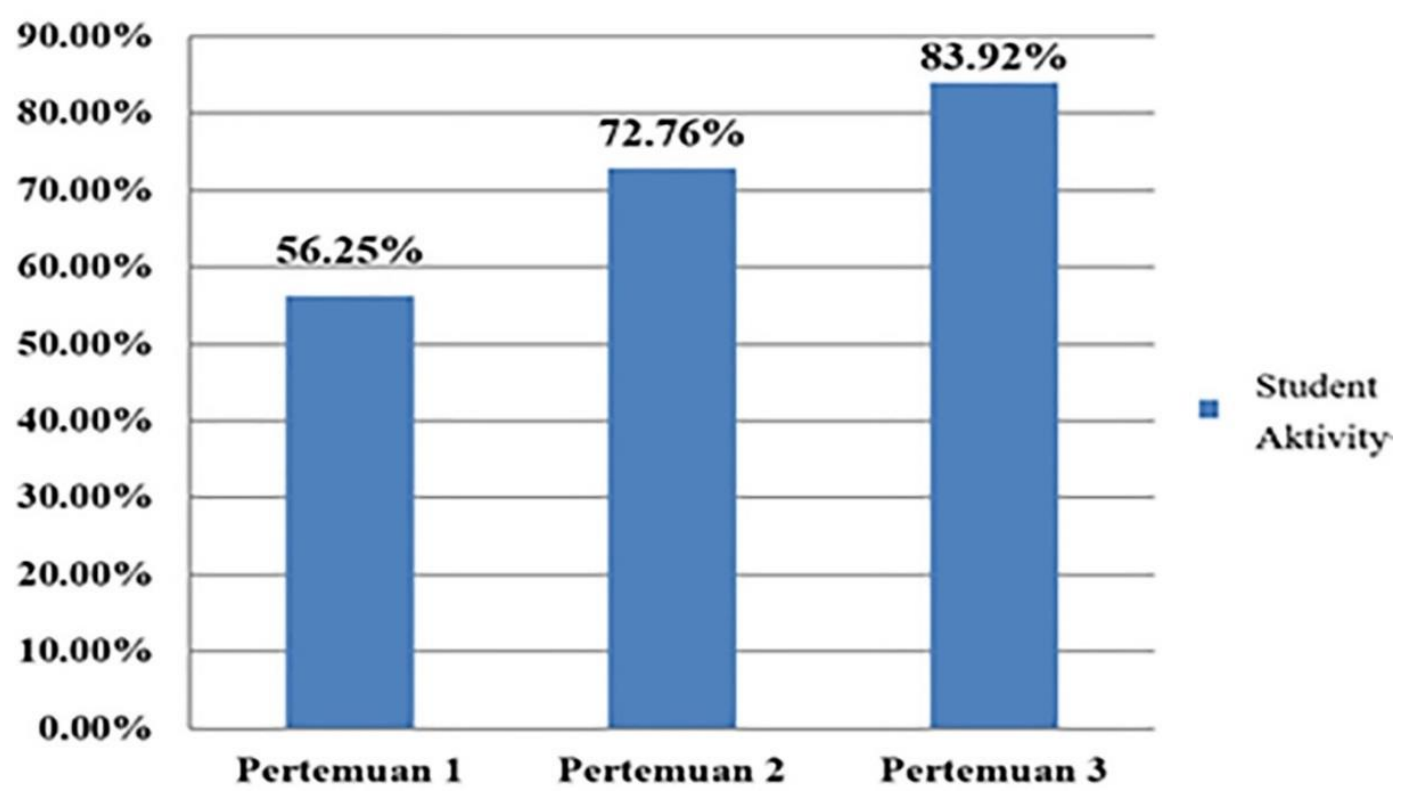

Graph 4.1 Increasing Student Activity 
Completeness of Student Learning in Online Classes

Based on the analysis of student learning outcomes scores, information was obtained that the application of the recitation method in the online classroom learning process had increased student learning outcomes between precycle, first cycle, and second cycle in accounting subjects, especially in General Entries and Ledgers. (General ledger). For a clearer comparison of student scores, it can be seen in table 4.4 below.

Table 4.4 Comparison of Student Values. Pre-cycle, Cycle I, and Cycle II

\begin{tabular}{llll}
\hline Information & Pra Siklus & Siklus I & Siklus II \\
\hline The highest score & 80 & 90 & 100 \\
Lowest Value & 45 & 60 & 65 \\
Number of Students Not Complete & 9 & 5 & 1 \\
Number of Completed Students & 5 & 9 & 13 \\
Average & 63,92 & 71,78 & 77,85 \\
Classical Completeness Percentage & $35 \%$ & $64,28 \%$ & $92,85 \%$ \\
\hline
\end{tabular}

The increase in the average value and the percentage of completeness of student learning outcomes in the precycle, cycle I, and cycle II can be seen in diagrams 4.2 and 4.3 as follows:

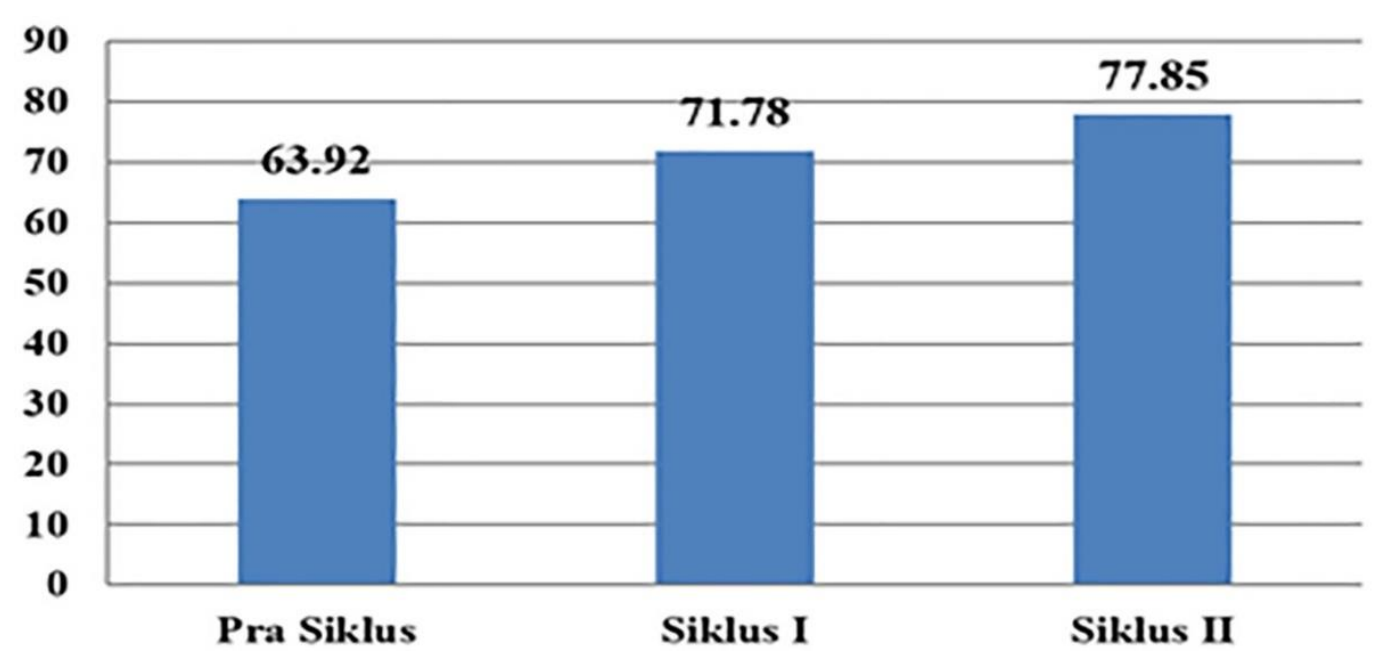

Graph 4.2 Average Score

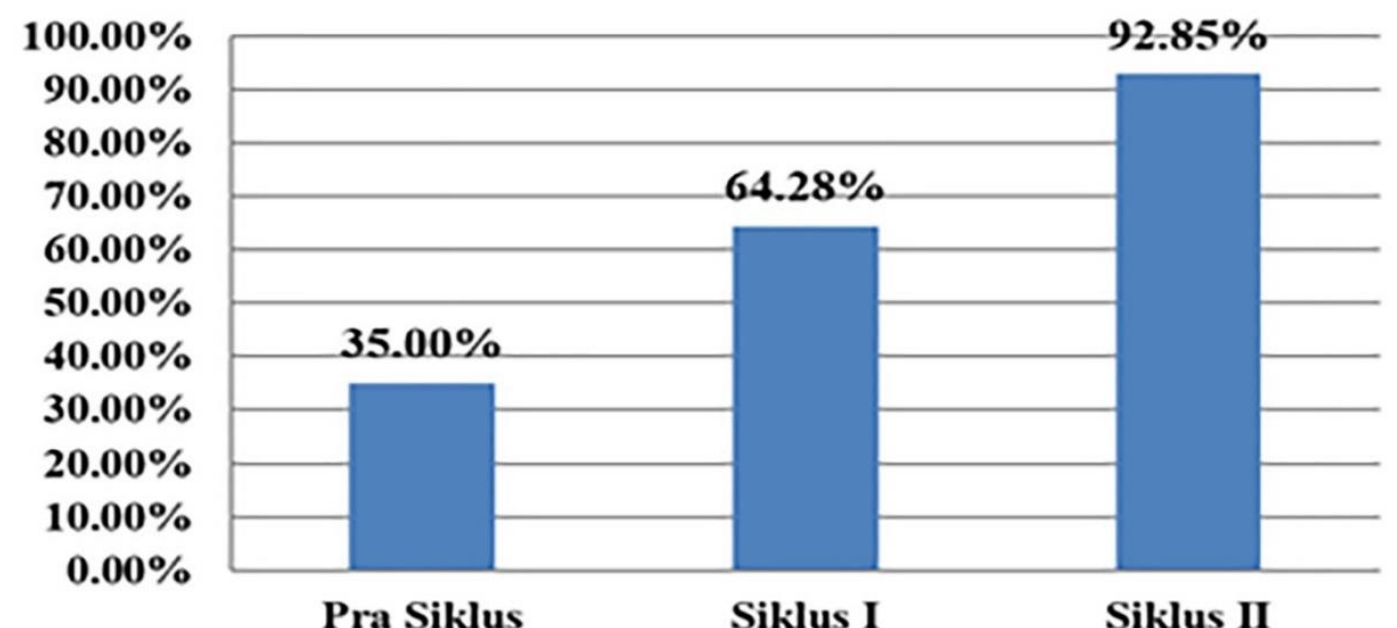

Graph 4.3 Percentage of Student Learning Completeness

In graphs 4.2 and 4.3, the increase in student learning outcomes can be seen from the scores before the online class CAR Implementation using the online class recitation method until the end of the second cycle of online class learning outcomes. Before CAR (Pre-Cycle) the average value of the class was 63.92 with classical learning 
completeness of $35 \%$. Learning outcomes in the first cycle reached an average of 71.78 with a classical learning completeness level of $64.28 \%$. While the learning outcomes in the second cycle reached an average of 77.85 with the classical learning completeness level reaching $92.85 \%$. This proves that there is an increase in student learning outcomes after classroom actions are carried out with the application of the online class recitation method in the learning process on Accounting subjects, with the subject matter of General Journals (General Entries) and General Ledgers in online classes during the covid 19 pandemic.

\section{Conclusions}

Based on the results of the analysis and discussion of problems in online classroom learning during the civid 19 pandemic, it can be concluded that the application of the recitation method in online classroom learning during the covid-19 pandemic, can improve student learning outcomes in class XI accounting subjects majoring in SMK accounting. Negeri 1 Tompaso Baru, especially in the accounting cycle material for service companies with the following stages: Recording Transactions/Documents into General Journals (General Entries) and Posting from General Journals to General Ledgers (General Ledger).

This increase can be seen from the percentage of students' completeness individually and classically. At the precycle stage or before the implementation of the action, the average value of the class was 63.92 with the percentage of classical learning completeness only 35\%, in the first cycle it reached an average of 71.78 with a classical learning completeness level of $64.28 \%$. While the learning outcomes in the second cycle reached an average of 77.85 with the classical learning completeness level reaching 92.85\%. Likewise with student learning activities at each meeting. Student activity at the 1st meeting only reached a percentage of $56.25 \%$ with high criteria, at the 2nd meeting it reached a percentage of $72.76 \%$ with high criteria, and at the 3rd meeting it reached a percentage of $83.92 \%$ with criteria very high. Thus student learning activity and student learning completeness in online classes during the covid 19 pandemic increase by using the recitation learning method,

From the results of this study, it is recommended that teachers in carrying out learning tasks during the Covid-19 pandemic, should use learning from the recitation method.

\section{References}

Adriantoni, Nurdin Syafruddin (2016). Curriculum and Learning, Jakarta, Rajawali Press.

Aqib, Zainal, et al. (2010). Classroom Action Research. Bandung: Yrama Widya.

Arikunto, Suharsimi, et al. (2018). Classroom Action Research. Jakarta: Earth Literacy

Arikunto, Suharsimin (2010). Research Management. Jakarta, Renaka Cipta.

BSNP. (2017). Guidelines for Assessment of Learning Outcomes in Elementary Schools. Jakarta: Ministry of National Education

Decree of the Minister of Education and Culture of the Republic of Indonesia No. 36962/MPK_A/HK/2020, Regarding Covid 19 Response and Online Learning.

Dimyati, et al. (2012). Learning And Learning. Jakarta: Rineka Cipta.

Djamarah, Zain (2016). Teaching and Learning Strategy. Rineka Cipta: Jakarta.

Elfis. (2016). Classroom Action Research Methodology Teaching Materials. Pekanbaru: FKIP UIR

Government Regulation No. 17 of 2010, concerning: Management and Implementation of Education, East Java, Yogyakarta

Hamzah, B. Uno (2011). Learning Planning, Jakarta, Bumi Aksara.

Maya, Sari, Yuni (2008). Application of the Recitation Method to Improve Mathematics Learning Outcomes of Class VIII.F Students of SMP Negeri 25 Pekanbaru in the 2007/2008 Academic Year. Retrieved December 19, 2014 from http://kamiluszaman.blogspot.com/2014/11/application-method-recitation

Moleong, Lexy J. (2000). Qualitative Research Methodology. PT. Remaja Rosdakarya, Bandung.

Muslich, Masnur. (2017). Implementing Classroom Action Research CAR is Easy. Jakarta: Earth Literacy.

RI Law No. 20 of 2003, concerning: National Education System, Indonesian Legislation Association, concerning: National Education Agency, Complete Edition, 2009. MP. Media Purnama Bandung.

Rochiati Wiriaatmadja. (2015). Classroom Action Research Methods. Bandung: PT. Rosdakarya Youth.

Roestiyah, N. K. (2018). Teaching and Learning Strategy. PT. Character Building. Jakarta.

Rusly, M. (2009). Communication and Information Technology in Education, UNESCO Expert in Language. Jakarta, Dress Persada (GP Press).

Saputro, Suprihadi (2013). Fundamentals of General Teaching Methodology. Malang: IKIP Malang. 
Sari, sunindar, auliyawati. (2005). Effect of motivation, learning methods and Environment on accounting learning achievement in class XI Social science of SMA Negeri 1 Karanganom Klaten. Retrieved December 19, 2014 from http://one.indoscription.com/

Slamet (2012). Teaching and Learning Process in the Credit System (SKS). Jakarta: Earth Literacy

Slameto (2012). Learning and Factors That Affect It, Jakarta: Rineka Cipta.

Soekartiwi (2013). Improving Teaching Effectiveness. Jakarta: Dunia Pustaka Raya.

Sudjana, Nana (2010). Assessment of Teaching and Learning Outcomes. (Ct. XV). Bandung: PT. Rosdakarya Teens

Syafrudin Nurdin (2016). Curriculum and Learning: Rajawali Press. Jakarta

Yonny, Acep, et al. (2010). Compiling Classroom Action Research. Yogyakarta: Family.

Yudhistira, D. (2016. Compiling a Scientific Paper that Meets the "APIK" Criteria. Jakarta: PT. Grasindo.

\section{Notes}

Note 1. (Wina Sanjaya, 2010:13)

Note 2. (Slameto, 2013:11)

Note 3. (Syafruddin Nurdin, 2016:20).

Note 4. (Suharsimi Arikunto et al, 2018).

Note 5. (Rochiati Wiriaatmadja, 2015:66).

Note 6. Syafruddin Nurdin, Adriantoni (2006: 95),

Note 7. Lexy J. Moleong, (2000: 15)

Note 8. Suharsimin Arikunto (2010: 268)

Note 9. Formula Explanation ; (Acep Yonny, et al 2010: 175-176)

Note 10. To determine the average grade point (Nana Sudjana, 2010: 125):

Note 11. To determine the level of classical learning completeness according to Zainal Aqib et al., (2010: 41)

\section{Copyrights}

Copyright for this article is retained by the author(s), with first publication rights granted to the journal.

This is an open-access article distributed under the terms and conditions of the Creative Commons Attribution license (http://creativecommons.org/licenses/by/4.0/). 